\section{KOMPASS}

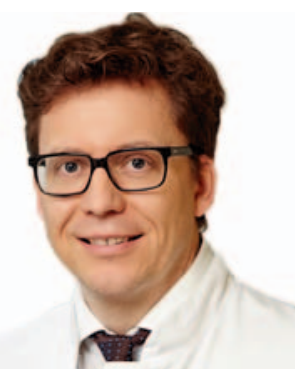

Prof. Dr. Christian Schumann

Klinik für Pneumologie, Thoraxonkologie, Schlaf- und Beatmungsmedizin, Klinikverbund Kempten-Oberallgäu gGmbH

\title{
Rauchstopp-Strategien bei Lungenkrebs
}

\author{
Ausgewählt und kommentiert von \\ Prof. Dr. Christian Schumann \\ (Klinikverbund Kempten-Oberallgäu)
}

\begin{abstract}
«Rauchen verursacht Lungenkrebs» - diese Warnung auf Zigarettenschachteln ist zugleich wichtiger Hintergrund von Motivationsstrategien bei multiplen Raucherentwöhnungsprogrammen in entwickelten Industrieländern. Erste Erfolge sind in einer Abnahme der Zahl der aktiven Raucher und in einer Stabilisierung der Neuerkrankungsraten an Lungenkrebs zu sehen. Seit einigen Jahren besteht eine zunehmende Evidenz, dass Patienten mit Lungenkrebs, die Rauchen, eine erhöhte Sterblichkeit und ein erhöhtes Risiko für Zweitmalignome aufweisen. Gleichzeitig verbessert Rauchstopp mit der Diagnose Lungenkrebs das Überleben der Patienten während einer Tumorbehandlung. Stone et al., zeigen deutlich, welches Potenzial im Rauchstopp bei Lungenkrebs steckt, stehen aber auch selbstkritisch ein, dass viele Kliniker keine aktiven Rauchstopp-Strategien mit in die Behandlung von Lungenkrebs einsetzen.
\end{abstract}

\section{Lungenkrebs-Screening}

50\% der Patienten in den Studien zum Lungenkrebs-Screening waren Raucher (Infante et al.). Das Potenzial für eine erfolgreiche Raucherentwöhnung wird in dieser Situation hoch eingestuft, insbesondere wenn kontrollbedürftige Befunde in der Low-dose-Computertomographie (LDCT) resultierten (NLCST) (Zeliadt). Auf der anderen Seite führten unauffällige LDCT-Befunde zu einer Abnahme der Rauchstopp-Motivation (Tammemägi et al.).

\section{Patienten mit Frühkarzinomen der Lunge (Rauchen und Operation)}

Die postoperativen Risiken sind bei Rauchern erhöht; entgegen der langjährigen Meinung, dass eine initial vermehrte Mucusbildung durch Rauchstopp erstmal nachteilig sei. Aktuelle Studien zeigen deutlich eine erhöhte Mortalität und pulmonale Komplikationsrate bei Rauchern und ähnliche Risiken bei Patienten mit aktuellem Rauchstopp im Vergleich zu Menschen, die noch nie geraucht hatten (Mason et al., Groth et al.).

\section{Patienten mit fortgeschrittenem Lungenkrebs}

Mit der Erstdiagnose Lungenkrebs ist die aktive Tumortherapie, meist in Form einer Systemtherapie, für Patienten und Therapeuten vordergründig. Nichtraucher-Strategien werden in dieser ersten Phase der Krebstherapie unzureichend beachtet. Es existieren Daten, dass Rauchstopp sicher und effektiv ist und dass eine frühe Intervention (innerhalb von 3 Monaten nach Erstdiagnose) zu einer doppelt so hohen Abstinenzrate führen kann (Leone et al., Sanderson Cox et al.).

Zusammenfassend ist festzustellen, dass Strategien der Rauchentwöhnung mit der Krebsbehandlung kombinierbar sind. Obwohl keine randomisierten Daten existieren, die harte Endpunkte bezüglich der Intervention «Rauch-Entwöhnung» untersuchten, besteht groBes Potenzial in der Rauchentwöhnung auch bei Diagnose Lungenkrebs.

\section{KARGER}

(๑) 2017 S. Karger GmbH, Freiburg

Fax +497614520714

information@karger.com

www.karger.com 
Stone E, Vachani A: Tobacco control and tobacco cessation in lung cancer - too little, too late? Semin Respir Crit Care Med 2016;37:649-658.

The lung cancer epidemic of the twentieth century grew out of increasing tobacco consumption in the first half of that century. Tobacco control policies have been instituted in many high-income countries since the mid-1960s. Since then smoking rates have declined in these countries, particularly in men where lung cancer rates have stabilized. Tobacco control measures are not strong enough in many countries around the world, particularly low and middle income countries in Eastern Europe and Asia. In these countries, smoking rates and lung cancer rates remain high. Tobacco cessation is more successful in countries with stronger tobacco control and confers quality of life and survival benefits in smokers including lung cancer patients. A significant degree of stigma surrounds the diagnosis of lung cancer which is often considered "self-inflicted" even though the tobacco industry promotes smoking uptake and maintenance. Sustained, effective tobacco control and cessation may improve lung cancer outcomes and are key considerations in modern care of lung cancer patients.

Infante M, Cavuto S, et al., DANTE Study Group: Longterm follow-up results of the DANTE trial, a randomized study of lung cancer screening with spiral computed tomography. Am J Respir Crit Care Med 2015;191:1166-1175.

Screening for lung cancer with low-dose spiral computed tomography (LDCT) has been shown to reduce lung cancer mortality by $20 \%$ compared with screening with chest X-ray (CXR) in the National Lung Screening Trial, but uncertainty remains concerning the efficacy of LDCT screening in a community setting.

Objectives: To explore the effect of LDCT screening on lung cancer mortality compared with no screening. Secondary endpoints included incidence, stage, and resectability rates.

Methods: Male smokers of 20+ pack-years, aged 60 to 74 years, underwent a baseline CXR and sputum cytology examination and received five screening rounds with LDCT or a yearly clinical review only in a randomized fashion. Measurements and Main Results: A total of 1,264 subjects were enrolled in the LDCT arm and 1,186 in the control arm. Their median age was 64.0 years (interquartile range, 5), and median smoking exposure was 45.0 pack-years. The median follow-up was 8.35 years. One hundred four patients $(8.23 \%)$ were diagnosed with lung cancer in the screening arm ( 66 by CT), 47 of whom (3.71\%) had stage I disease; 72 control patients (6.07\%) were diagnosed with lung cancer, with 16 (1.35\%) being stage I cases. Lung cancer mortality was 543 per 100,000 person-years (95\% confidence interval, 413-700) in the LDCT arm versus 544 per 100,000 person-years (95\% CI, 410-709) in the control arm (hazard ratio, 0.993; 95\% confidence interval, 0.688-1.433).

Conclusions: Because of its limited statistical power, the results of the DANTE (Detection And screening of early lung cancer with Novel imaging TEchnology) trial do not allow us to make a definitive statement about the efficacy of LDCT screening. However, they underline the importance of obtaining additional data from randomized trials with intervention-free reference arms before the implementation of population screening.
Zeliadt SB, Heffner JL, Sayre G, et al.: Attitudes and perceptions about smoking cessation in the context of lung cancer screening. JAMA Intern Med 2015;175: 1530-1537.

Importance: Broad adoption of lung cancer screening may inadvertently lead to negative population health outcomes if it is perceived as a substitute for smoking cessation.

Objective: To understand views on smoking cessation from current smokers in the context of being offered lung cancer screening as a routine service in primary care.

Design, Setting, and Participants: As an ancillary study to the launch of a lung cancer screening program at 7 sites in the Veterans Health Administration, 45 in-depth semi-structured qualitative interviews about health beliefs related to smoking and lung cancer screening were administered from May 29 to September 22, 2014, by telephone to 37 current smokers offered lung cancer screening by their primary care physician. Analysis was conducted from June 15, 2014, to March 29, 2015.

Main Outcomes and Measures: Attitudes and perceptions about the importance of smoking cessation in the context of lung cancer screening.

Results: Lung cancer screening prompted most current smokers to reflect for the first time on what smoking means for their current and future health. However, 17 of 35 (49\%) participants described mechanisms whereby screening lowered their motivation for cessation, including the perception that undergoing an imaging test yields the same health benefits as smoking cessation. Other misperceptions include the belief that everyone who participates in screening will benefit; the belief that screening and being able to return for additional screening offers protection from lung cancer; the perception by some individuals that findings from screenings have saved their lives by catching their cancer early when indeterminate findings are identified that can be monitored rather than immediately treated; and a reinforced belief in some individuals that a cancer-free screening test result indicates that they are among the lucky ones who will avoid the harms of smoking.

Conclusions and Relevance: In this qualitative, lung cancer screening prompted many current smokers to reflect on their health and may serve as a potential opportunity to engage patients in discussions about smoking cessation. However, several concerning pathways were identified in which screening, when offered as part of routine care and described as having proven efficacy, may negatively influence smoking cessation. Health care professionals should be aware that the opportunity for early detection of lung cancer may be interpreted as a way of avoiding the harms of smoking. To promote cessation, discussions should focus on the emotional response to screening rather than clinical details (eg, nodule size) and address misperceptions about the value of early detection so that screening does not lower motivation to quit smoking.

\section{Tammemägi MC, Berg CD, Riley TL, et al.: Impact of lung cancer screening results on smoking cessation. J Natl Cancer Inst 2014;106:dju084.}

Background: Lung cancer screening programs may provide opportunities to reduce smoking rates among participants. This study evaluates the impact of lung cancer screening results on smoking cessation.

Methods: Data from Lung Screening Study participants in the National Lung Screening Trial (NLST; 2002-2009) were used to prepare multivariable longitudinal regression models predicting annual smoking cessation in those who 
were current smokers at study entry $(n=15489$, excluding those developing lung cancer in follow-up). The associations of lung cancer screening results on smoking cessation over the trial period were analyzed. All hypothesis testing used two sided P values.

Results: In adjusted analyses, smoking cessation was strongly associated with the amount of abnormality observed in the previous year's screening $(\mathrm{P}<$ .0001). Compared with those with a normal screen, individuals were less likely to be smokers if their previous year's screen had a major abnormality that was not suspicious for lung cancer (odds ratio $[\mathrm{OR}]=0.811 ; 95 \%$ confidence interval $[\mathrm{CI}]=0.722$ to $0.912 ; \mathrm{P}<.001)$, was suspicious for lung cancer but stable from previous screens $(\mathrm{OR}=0.785 ; 95 \% \mathrm{CI}=0.706$ to $0.872 ; \mathrm{P}<.001)$, or was suspicious for lung cancer and was new or changed from the previous screen $(\mathrm{OR}=0.663 ; 95 \% \mathrm{CI}=0.607$ to $0.724 ; \mathrm{P}<.001)$. Differences in smoking prevalence were present up to 5 years after the last screen.

Conclusions: Smoking cessation is statistically significantly associated with screen-detected abnormality. Integration of effective smoking cessation programs within screening programs should lead to further reduction in smoking-related morbidity and mortality.

\section{Mason DP, Subramanian S, Nowicki ER, et al.: Impact of smoking cessation before resection of lung cancer: a Society of Thoracic Surgeons General Thoracic Surgery Database study. Ann Thorac Surg 2009;88:362-370.}

Background: Smoking cessation is presumed to be beneficial before resection of lung cancer. The effect of smoking cessation on outcome was investigated. Methods: From January 1999 to July 2007, in-hospital outcomes for 7990 primary resections for lung cancer in adults were reported to the Society of Thoracic Surgeons General Thoracic Surgery Database. Risk of hospital death and respiratory complications was assessed according to timing of smoking cessation, adjusted for clinical confounders.

Results: Hospital mortality was $1.4 \%(\mathrm{n}=109)$, but $1.5 \%$ in patients who had smoked (105 of 6965) vs $0.39 \%$ in those who had not (4 of 1025). Compared with the latter, risk-adjusted odds ratios were $3.5(p=0.03), 4.6(p=0.03), 2.6$ $(\mathrm{p}=0.7)$, and $2.5(\mathrm{p}=0.11)$ for those whose timing of smoking cessation was categorized as current smoker, quit from 14 days to 1 month, 1 to 12 months, or more than 12 months preoperatively, respectively. Prevalence of major pulmonary complications was $5.7 \%$ (456 of 7965) overall, but $6.2 \%$ in patients who had smoked (429 of 6941) vs $2.5 \% \%$ in those who had not (27 of 1024). Compared with the latter, risk-adjusted odds ratios were $1.80(\mathrm{p}=0.03), 1.62$ $(\mathrm{p}=0.14), 1.51(\mathrm{p}=0.20)$, and $1.29(\mathrm{p}=0.3)$ for those whose timing of smoking cessation was categorized as above.

Conclusions: Risks of hospital death and pulmonary complications after lung cancer resection were increased by smoking and mitigated slowly by preoperative cessation. No optimal interval of smoking cessation was identifiable. Patients should be counseled to stop smoking irrespective of surgical timing.

\section{Groth SS, Whitson BA, Kuskowski MA, et al.: Impact of} preoperative smoking status on postoperative complication rates and pulmonary function test results 1-year following pulmonary resection for non-small cell lung cancer. Lung Cancer 2009;64:352-357.

There is a lack of evidence in the literature regarding the impact of preoperative smoking status on pulmonary function test (PFT) results 1 year after resection for non-small cell lung cancer (NSCLC). Furthermore, there is dis- agreement in the literature regarding the impact of preoperative smoking cessation on postoperative complication rates. We performed a single-institution retrospective review of all NSCLC patients who underwent resection from April 2000 through April 2006. Timing of smoking cessation was stratified as follows: smoking cessation more than a month before surgery (Distant Smokers), smoking cessation within a month before surgery (Recent Smokers), and failure to achieve smoking cessation before surgery (Current Smokers). During the study period, 213 patients underwent NSCLC resection, 121 of whom (all males; mean age, 67.4 years) completed pre- and postoperative PFTs. After adjusting for potential confounding covariates (age, type of resection, and use of radiation therapy), we noted no significant difference $(p>0.40)$ between groups after resection with regard to either relative $(-12.20+/-15.77 \mathrm{~L}$ [Distant Smokers], -15.38+/-19.38L [Recent Smokers], $-9.61+/-15.54 \mathrm{~L}$ [Current Smokers]) or absolute changes in percent predicted forced expiratory volume in 1 s $(-0.14+/-0.20 \mathrm{~L}$ [Distant Smokers], $-0.18+/-$ 0.19L [Recent Smokers], -0.12+/-0.20L [Current Smokers]). Because 92 patients did not complete postoperative PFTs, we performed a stratified analysis to assess for selection bias; as compared with those who completed PFTs, baseline PFT results did not significantly differ. We found no significant differences between the 3 groups with regard the overall rate of postoperative complications or the rate of any specific postoperative complication. In conclusion, smoking cessation immediately before NSCLC resection does not significantly impact postoperative pulmonary complication rates or 1-year postoperative PFT results and therefore should not be a reason to delay surgical resection.

Leone FT, Evers-Casey S, Toll BA, Vachani A: Treatment of tobacco use in lung cancer: diagnosis and mangement of lung cancer, 3rd ed: ACCP evidence-based clinical practice guidelines. Chest 2013;143(suppl 5):e61S-e77S.

Background: Continued tobacco use in the setting of lung cancer management is frequently confounding and always of critical importance. We summarized the published literature concerning the management of tobacco dependence in patients with lung cancer and offer recommendations for integrating dependence treatment into ongoing oncologic care.

Methodology: MEDLINE, Embase, CINAHL, PsychINFO, and the Cochrane Collaborative databases were searched for English language randomized clinical trials, cohort studies, case-control studies, secular trend analyses, and case series relevant to the a priori identified clinical questions. Evidence grading, integration, and genesis of recommendations followed the methods described in "Methodology for Development of Guidelines for Lung Cancer" in the American College of Chest Physicians Lung Cancer Guidelines, 3rd ed. Results: We describe the approach to tobacco dependence in patients with lung cancer at various phases in the evolution of cancer care. For example, among patients undergoing lung cancer screening procedures, we recommend against relying on the screening itself, including procedures accompanied solely by self-help materials, as an effective strategy for achieving abstinence. Among patients with lung cancer undergoing surgery, intensive perioperative cessation pharmacotherapy is recommended as a method for improving abstinence rates. Cessation pharmacotherapy is also recommended for patients undergoing chemotherapy, with specific recommendations to use bupropion when treating patients with lung cancer with depressive symptoms, as a means of improving abstinence rates, depressive symptoms, and quality of life. 
Conclusions: Optimal treatment of lung cancer includes attention to continued tobacco use, with abstinence contributing to improved patient-related outcomes at various phases of lung cancer management. Effective therapeutic interventions are available and are feasibly integrated into oncologic care. A number of important clinical questions remain poorly addressed by the existing evidence.

\section{Sanderson Cox L, Patten CA, Ebbert JO, et al.: Tobacco use} outcomes among patients with lung cancer treated for nicotine dependence. J Clin Oncol 2002;20:3461-3469.

Purpose: There is a current lack of consensus about the effectiveness of nicotine dependence treatment for cancer patients. This retrospective study examined the 6-month tobacco abstinence rate among lung cancer patients treated clinically for nicotine dependence.

Patients and Methods: A date-of-treatment matched case control design was used to compare lung cancer patients (201 lung cancer patients, $41 \%$ female) and nonlung cancer patients (201 controls, $45 \%$ female) treated in the Mayo
Clinic Nicotine Dependence Center between 1988 and 2000. The intervention involves a brief consultation with a nicotine dependence counselor. A treatment plan individualized to the patient's needs is then developed. The primary end point was the self-reported, 7-day point prevalence abstinence from tobacco at 6-month follow-up.

Results: At baseline, compared with the controls, the lung cancer patients were significantly older $(\mathrm{P}<.001)$, reported higher motivation to stop smoking ( $\mathrm{P}=.003)$, and were at a higher stage of change $(\mathrm{P}=.002)$. The 6 -month tobacco abstinence rate was $22 \%$ for the lung cancer patients compared with $14 \%$ of the control patients ( $\mathrm{P}=.024)$. After adjusting for age, sex, baseline cigarettes smoked per day, and stage of change, no significant difference was detected between lung cancer patients and controls on the tobacco abstinence rate.

Conclusion: The results suggest that nicotine dependence treatment is effective for patients with a diagnosis of lung cancer. The majority of lung cancer patients were motivated to stop smoking. 